Wojciech Sadłoń

\title{
Zacieśnianie czy rozrywanie immanentnej ramy? Polski katolicyzm wobec epidemii koronawirusa
}

\begin{abstract}
Streszczenie: W artykule tym analizuję zmianę wewnętrznej dynamiki katolicyzmu w okresie pandemii. W pierwszej części prezentuję dynamikę instytucjonalnych działań wywołanych poczuciem zagrożenia przez COVID-19. Następnie charakteryzuję dynamizm polskiego katolicyzmu, uwypuklając jego 1) takie cechy jak: masowość, przenikanie się parafii oraz społeczności lokalnej na wsi, rolę małych grup duszpasterskich; 2) kierunki przemian, takie jak: erozja wspólnotowych rytuałów, instytucjonalnego wysycenia, zerwania ciągłości socjalizacji religijnej, spadku zaufania do katolicyzmu; 3) czynniki socjalizacji religijnej, takie jak rodzina oraz media. Analiza dostępnych danych empirycznych prowadzi mnie do wniosku, że epidemia nałożyła na polski katolicyzm swoistą formę, która ograniczyła zasięg interakcji i praktyk zbiorowych oraz wzmacnia obserwowany przynajmniej od dwóch dekad proces słabnięcia religijnych praktyk zbiorowych oraz więzi z parafią. Jednocześnie epidemia wzmacnia proces dyferencjacji oraz kluczowe dla polskiego katolicyzmu powiązanie więzi rodzinnych i religijności.
\end{abstract}

Słowa kluczowe: katolicyzm, COVID-19, religijność.

\section{Wprowadzenie}

Wybuch epidemii koronawirusa był wstrząsem, który uruchomił nowe procesy w społeczeństwie polskim. Wpływ epidemii dotyczy bez wątpienia również religii. Jej oddziaływanie na religijność zależy nie tylko od samych ograniczeń i restrykcji związanych z epidemią, ale również od dynamiki samej religijności, a ta w polskim społeczeństwie jest bardzo specyficznie ukształtowana przez historyczne procesy. W publikowanej wstępnie od kilku miesięcy literaturze $\mathrm{z}$ zakresu socjologii religii zagadnienie epidemii koronawirusa rozpatrywane jest głównie pod kątem wpływu religijności na zachowania związane z epidemią, czyli przede wszystkim na przestrzeganie restrykcji oraz tzw. reżimu sanitarnego. Wynika z nich, że w Stanach

Dr Wojciech Sadłoń, Uniwersytet Kardynała Stefana Wyszyńskiego, Wydział Nauk Humanistycznych, Instytut Statystyki Kościoła Katolickiego SAC im. Witolda Zdaniewicza, w.sadlon@iskk.pl, ORCID: 0000-0002-2412-6607. 
Zjednoczonych $\mathrm{w}$ regionach bardziej religijnych przestrzeganie restrykcji było mniejsze (Hill i in. 2020). Wyjaśnieniem takiej statystycznej zależności jest wpływ tzw. religijnej ideologii, która prowadzić ma do zwątpienia w naukę oraz dystansowania się od opartych na faktach naukowych strategii (evidence-based policy) (Baker i in. 2020). Jednak, jak wykazali Samuel L. Perry, Andrew L. Whithead i Joshua B. Grubbs (2020), to raczej nie sama religijność, lecz „nacjonalizm” rozumiany jako przekonanie o specjalnej fuzji między życiem społecznym a tożsamością chrześcijańską stanowi wyjaśnienie lekceważenia restrykcji sanitarnych. Natomiast religijność rozumiana jako praktyki religijne, ważność religii oraz częstość modlitwy wiązała się z częstszym i pełniejszym przestrzeganiem obostrzeń. Inne badania (Mc Daniel i in. 2011) wskazują, że wiara definiowana jako relacja z Bogiem rozumianym jako „siła wyższa” wzbudza w jednostce przekonanie o byciu wybranym i chronionym przez Boga, czyli o boskiej opiece (Opatrzności). Ponadto w narracji osób wierzących w Stanach Zjednoczonych pojawia się tendencja do traktowania pandemii jako boskiego ostrzeżenia i wezwania do nawrócenia.

W tym artykule nie chcę badać wpływu religijności na zachowania związane z epidemią, lecz raczej zmianę wewnętrznej dynamiki (morfogenezy) katolicyzmu w czasie pandemii. Moim celem nie jest dokonywanie porównywania religijności Polaków z religijnością innych społeczeństw, lecz raczej ukazanie wewnętrznej dynamiki. Tak więc ten artykuł jest próbą ukazania wpływu epidemii koronawirusa na dynamizm katolicyzmu w Polsce. Jako perspektywę badawczą przyjmuję spojrzenie na polskim katolicyzm niejako od wewnątrz. Opierając się na rozróżnieniu zaproponowanym przez Margaret Archer (1995; 1998; 2000), zwracam uwagę zarówno na kulturowe, jak i społeczno-kulturowe aspekty funkcjonowania polskiego katolicyzmu. Przez katolicyzm rozumiem system społeczno-kulturowy będący w procesie ciągłego kształtowania się (morfogenezy) i zawierający nie tylko zespół idei i treści, ale również oparty na interakcjach oraz komunikacji. Katolicyzm oznacza określony strumień nie tylko narracji zawierających treści związane z dogmatyką chrześcijańską, ale również system działań i praktyk odnoszących się w sposób bardziej lub mniej bezpośredni do tradycyjnych katolickich instytucji. Pandemia koronawirusa stanowi istotną okoliczność oraz kontekst wpływający na proces kształtowania się tak rozumianego polskiego katolicyzmu.

Aby nadać tej analizie nieco szerszą perspektywę oraz teoretyczną podstawę, odwołuję się do pojęcia „immamentnej ramy”, którą Charles Taylor (2007) wykorzystuje do ukazania swoistego kryzysu religii w zachodnim świecie. „Immanentna rama” oznacza specyficzny splot procesów oraz współczesnych uwarunkowań, w jakim funkcjonuje dzisiaj jednostka, które 1) kształtują wyraźny podział między państwem i Kościołem; 2) odciągają jednostkę od zaangażowania w wiarę i stawiają wiarę w opozycji do nauki; 3) sprawiają, że życie wiarą staje się coraz mniej 
oczywiste i skupia jednostkę coraz bardziej na tym, co immanentne. Taylorowska kategoria „immanentnej ramy” zakłada przeciwstawienie jakości życia (dobrosta$\mathrm{nu}$ ) i rozwoju podmiotowego (human flourishing) celom transcendentnym - a więc w konsekwencji krystalizowanie się opozycji humanizmu i religii. Wyjaśnienie procesu sekularyzacji z zastosowaniem kategorii immanentnej ramy polega na tym, że współczesne procesy społeczne kształtują „ekskluzywny humanizm”, w którym religia przestaje mieć znaczenie. Według Taylora współcześnie „dochodzi do przyćmienia wszystkich celów wykraczających poza ludzki rozwój [human flourishing]" (Taylor 2007, s. 19-20), a współczesna debata dotycząca religii toczy się pomiędzy dwiema skrajnościami - „transcendentną religią z jednej strony oraz jej frontalnym zaprzeczeniem" (tamże, s. 20). Dzieje się tak, ponieważ narracja religijna i zawarte $w$ niej doświadczenie transcendencji oddalają się coraz bardziej od celu, jaki stawia sobie współczesny człowieka, czyli jego podmiotowego rozwoju (human flourishing). Człowiek w takim ujęciu staje więc przed wyborem pomiędzy tym, co ludzkie (humanizmem), a tym, co transcendentne - religią; pomiędzy swoim ludzkim, immanentnym rozwojem oraz transcendentalnymi celami. Religijność, $w$ tym przede wszystkim doświadczenie chrześcijańskie, znosi tę opozycję. Człowiek religijny odkrywa „miejsca spełnienia” (place of fullness) nie poza religią, lecz właśnie w obrębie kulturowego systemu religijnego (tamże). Wychodząc z takiego założenia, polski katolicyzm stanowi system kulturowy oraz powiązany z nim system interakcji, do którego człowiek religijny odnosi swoje doświadczenie spełnienia.

$\mathrm{W}$ tym tekście podchodzę do epidemii z perspektywy społecznej - jako do narzucanej przez państwo formy społecznych zachowań oraz interakcji. Innymi słowy, restrykcje oraz wprowadzone zalecenia rozumiem również jako swoistą behawioralną ramę, która określa i ogranicza funkcjonowanie polskiego katolicyzmu. W takiej perspektywie stawiam pytanie o to, na ile „rama” nałożona na polski katolicyzm w wyniku zagrożenia epidemią wzmacnia, a na ile przełamuje proces określany przez Taylora jako immanentna rama. W mojej analizie skupiam się przede wszystkim na okresie od połowy marca do końca maja 2020 r., a szczególną uwagę będę zwracał na funkcjonowanie wiejskiego katolicyzmu w czasie epidemii.

Ukazanie dynamiki polskiego katolicyzmu w nowym kontekście epidemii rozpocznę od zaprezentowania dynamiki instytucjonalnych działań wywołanych poczuciem zagrożenia przez COVID-19. W drugiej kolejności scharakteryzuję dynamizm polskiego katolicyzmu, uwypuklając jego: 1) cechy, takie jak: masowość, przenikanie się parafii oraz społeczności lokalnej na wsi, rolę małych grup duszpasterskich; 2) kierunki przemian, takie jak: erozja wspólnotowych rytuałów, instytucjonalnego wysycenia, zerwania ciągłości socjalizacji religijnej, spadku zaufania do katolicyzmu; 3) czynniki socjalizacji religijnej, takie jak rodzina oraz media. 
Zaprezentuję potencjalny wpływ epidemii na każdy z wymienionych aspektów funkcjonowania katolicyzmu w Polsce. Podejmując się takiej analizy, będę opierał się na wiedzy teoretycznej dotyczącej mechanizmów funkcjonowania systemu społeczno-kulturowego oraz wynikach badań empirycznych dotyczących zarówno katolicyzmu w Polsce, jak i oddziaływania epidemii na polskie społeczeństwo.

$\mathrm{W}$ tym rozdziale wykorzystuję dane $\mathrm{z}$ badania przeprowadzonego przez Centrum Badania Opinii Społecznej, sondażu firmy 4P oraz badań, w których uczestniczyłem osobiście. Tymi autorskimi badaniami, prowadzonymi w ramach Instytutu Statystyki Kościoła Katolickiego SAC im. Witolda Zdaniewicza jest: 1) pomiar praktyk religijnych w niedzielę 15 marca; 2) sondaż wśród czytelników Onet.pl; 3) analiza treści dziewięciu dzienników (w tym prowadzonych przez pięciu księży) osób pochodzących z następujących diecezji: tarnowskiej, krakowskiej, łódzkiej, lubelskiej, kieleckiej, częstochowskiej, łowickiej oraz warszawskiej ${ }^{1}$. Dzienniki były prowadzone przez osoby, które odpowiedziały pozytywnie na zaproszenie zawarte w komunikacie Instytutu Statystyki Kościoła Katolickiego opublikowanym przez Katolicką Agencję Informacyjną. Dodatkowo w tym artykule zostały uwzględnione, udostępnione Instytutowi Statystyki Kościoła Katolickiego przez firmę Nielsen Polska, dane dotyczące oglądalności mszy św. w telewizji².

\section{Nakładanie instytucjonalnej ramy}

Zanim jeszcze wirus fizycznie został przeniesiony do Polski przez wracającego z Niemiec pracownika, czyli przed 4 marca, Konferencja Episkopatu Polski zareagowała na epidemię 28 lutego $2020 \mathrm{r}$. W opublikowanym dokumencie przewodniczący Konferencji Biskupów abp Stanisław Gądecki zwrócił uwagę na „zasady higieny" oraz przypomniał, że dopuszczalne jest przyjmowanie komunii św. na rękę. Jednocześnie biskupi opublikowali informację dotyczącą zagrożenia COVID-19 sformułowaną przez ministra zdrowia Łukasza Szumowskiego. Już po wybuchu epidemii, 10 marca, przewodniczący Episkopatu w specjalnym komunikacie zachęcał do modlitwy w intencji jej ustania oraz do zastosowania szczególnych środków bezpieczeństwa w kościołach poprzez zwiększenie liczby mszy św., tak aby liczba wiernych była dostosowana do wprowadzonych limitów oraz do uczestniczenia w liturgii poprzez środki masowego przekazu.

Dwa dni później, czyli 12 marca, Komisja Stała Konferencji Episkopatu Polski zarekomendowała biskupom w poszczególnych diecezjach tzw. dyspensy z obowiązku uczestnictwa w niedzielnej mszy św. dla osób starszych, chorych, dzieci oraz

1 Bardzo dziękuję osobom, które zgodziły się prowadzić dzienniki w tak trudnym czasie.

2 Autor dziękuję Piotrowi Ciackowi za pomoc w uzyskaniu danych. 
tych, „którzy czują obawę przed zarażeniem”. Ponadto w wystosowanym dokumencie biskupi wprowadzili również zasady higieny dla księży sprawujących liturgię, przyjmowania komunii św. na rękę, niepodawania ręki w czasie znaku pokoju, zrezygnowania z napełniania kropielnic wodą święconą, nałożenia specjalnych folii na kratki konfesjonałów oraz zawieszenia pielgrzymek oraz rekolekcji szkolnych³.

13 marca 2020 r. minister zdrowia zarządził stan zagrożenia epidemicznego oraz wprowadził ograniczenie „sprawowania kultu religijnego w miejscach publicznych, w tym w budynkach i innych obiektach kultu religijnego" (par. 5. pkt 4) do 50 osób (Rozporządzenie Ministra Zdrowia 2020a). Tego samego dnia przewodniczący Episkopatu w specjalnym komunikacie poprosił biskupów diecezjalnych, aby ograniczyli liczbę osób na mszach św. również do 50 osób oraz zachęcał do codziennej modlitwy różańcowej o godz. $20.30 \mathrm{w}$ intencji ustania epidemii (Komunikat 2020a). W związku z tym, że za organizację życia religijnego na terenie diecezji odpowiada biskup diecezjalny, jeszcze tego samego dnia - czyli w piątek 13 marca - wszyscy biskupi diecezjalni wydali dekrety, które nakazały ograniczenie uczestnictwa we mszach św. już w najbliższą niedzielę. Przeprowadzona przeze mnie analiza tych dekretów wykazała, że różnice występowały jedynie na poziomie praktycznych rozwiązań dotyczących sposobu ograniczenia liczby osób na mszy św. Niektóre diecezje wprowadziły konkretne zalecenia, inne ograniczyły się tylko do zarządzenia dyspensy, niejako przenosząc na proboszczów obowiązek zadośćuczynienia zakazowi większych zgromadzeń, tak jak prezentuje to tabela 1. Kolejne restrykcje dotyczące liturgii wynikały z rozporządzenia ministra zdrowia z dnia 24 marca, w którym ograniczono liczbę osób uczestniczących w wydarzeniach o charakterze religijnym do pięciu osób, nie licząc osób sprawujących liturgię (Rozporządzenie Ministra Zdrowia 2020b), w ślad za którym biskupi diecezjalni również nakazali w swoich diecezjach ograniczenie liczby uczestników liturgii do pięciu.

W związku ze zbliżającymi się świętami wielkanocnymi 19 marca Kongregacja ds. Kultu Bożego i Dyscypliny Sakramentów opublikowała wytyczne dotyczące liturgii wielkanocnej, które zostało zaktualizowane 25 marca (Dekret 2020). Określały one, że czas świętowania Wielkanocy nie może być zmieniony, liturgia Wielkanocy powinna być sprawowana bez udziału wiernych, natomiast wierni powinni mieć możliwość uczestniczenia w niej poprzez transmisje. W Wielki Czwartek powinien zostać pominięty gest umycia nóg, w Wielką Sobotę liturgia nie powinna zawierać rozpalenia ogniska ani procesji. W ślad za tym dokumentem Prezydium Konferencji Episkopatu Polski wydało „Wskazania dla biskupów odnośnie do sprawowania

3 https://ekai.pl/zebranie-plenarne-episkopatu-przelozone-beda-obrady-rady-stalej (dostęp: 1.07.2020). 
czynności liturgicznych w najbliższych tygodniach", załączając w nim tekst Modlitwy błogosławieństwa stołu przed uroczystym positkiem w niedziele Zmartwychwstania Pańskiego (Wskazania 2020).

Tabela 1. Dekrety biskupów w diecezjach obrządku łacińskiego według wskazywanego głównego sposobu ograniczenia liczby wiernych na niedzielnej mszy św. w związku z zagrożeniem epidemicznym w 2020 r.

Table 1. Decrees by bishops in dioceses of the Latin rite according to the main method indicated for limiting the number of faithful at Sunday Mass. due to the epidemic threat in 2020

\begin{tabular}{lrr}
\hline & N & \% \\
\hline Ogółem łacińskich diecezji terytorialnych & 41 & 100 \\
Dyspensa od niedzielnego obowiązku & 25 & 61 \\
Odliczenie (wpuszczenie) tylko 50 osób do świątyni & 9 & 22 \\
Ograniczenie uczestników do osób zamawiających intencję mszy św. & 5 & 12 \\
Zwiększenie liczby mszy św. & 1 & 2 \\
Brak wskazania konkretnego rozwiązania & 1 & 2 \\
\hline
\end{tabular}

Źródło: badania własne.

Source: Own study.

Przewodniczący Episkopatu Polski poprosił również wszystkie parafie w Polsce, aby 25 marca w uroczystość Zwiastowania Pańskiego włączyły się w modlitwę z papieżem Franciszkiem w intencji ustania epidemii, za chorych, za służby medyczne oraz za zmarłych i zaproponował tekst modlitwy do odmówienia tego dnia. 26 marca Komisja Społeczna Episkopatu Polski wydała oświadczenie, w którym zachęciła do solidarności oraz do ograniczenia sporu politycznego (Oświadczenie 2020).

12 marca odwołana została również narodowa pielgrzymka do Rzymu z okazji setnej rocznicy urodzin Jana Pawła II. Na poziomie poszczególnych diecezji zawieszono udzielanie sakramentów, rekolekcje szkolne, spotkania grup duszpasterskich oraz pielgrzymki. Biskupi wzywali przede wszystkim do modlitwy w intencji służby zdrowia, ustania epidemii oraz solidarności z osobami starszymi. W swoich apelach zwracali uwagę $\mathrm{z}$ jednej strony na moralne zobowiązanie do stosowania się do obostrzeń sanitarnych, a z drugiej motywowali do większej duchowej i modlitewnej aktywności, natomiast duszpasterzy do większej dyspozycyjności. Również charytatywne instytucje katolickie podjęły przede wszystkim akcję organizowania pomocy osobom starszym w czasie epidemii. W niektórych parafiach inicjowano różnego rodzaju specjalne formy modlitwy, jak procesja księdza z Najświętszym 
Sakramentem po ulicach parafii. 19 marca media poinformowały o pierwszym przypadku zakażenia koronawirusem księdza katolickiego ${ }^{4}$.

Kolejny etap oddziaływania epidemii na funkcjonowanie polskiego katolicyzmu rozpoczął się 20 kwietnia, gdy minister zdrowia zwiększył limit osób mogących uczestniczyć w kulcie religijnym do jednej osoby na $15 \mathrm{~m}^{2}$ (Rozporządzenie Rady Ministrów 2020). Już wcześniej - 15 kwietnia - przewodniczący Episkopatu apelował w opublikowanym liście do premiera o „potrzebę bardziej spójnego, proporcjonalnego i sprawiedliwego kryterium ograniczania dopuszczalnej liczby wiernych w kościołach, podobnie jak to ma miejsce w przypadku innych podmiotów”. Zwracał uwagę, że "restrykcje nie powinny obejmować osób znajdujących się poza budynkiem sakralnym, do których stosują się ogólne przepisy o zachowaniu bezpiecznej odległości”, oraz zasugerował, aby od 20 kwietnia limit osób uczestniczących w liturgii został zwiększony do dziewięciu osób na $\mathrm{m}^{2}$ (List 2020a). Dopiero od 17 maja rząd zwiększył limity osób uczestniczących w liturgii do jednej osoby na $10 \mathrm{~m}^{2}$, a od 30 maja całkowicie zniesiono limit osób uczestniczących w liturgii. Zachowany został obowiązek zakrywania ust i nosa oraz zachowania dystansu dwóch metrów. 27 maja przewodniczący Episkopatu zachęcił biskupów diecezjalnych do zniesienia dyspensy od uczestniczenia w niedzielnej mszy św. za wyjątkiem osób starszych, chorych oraz tych, „które czują obawę przed zarażeniem" (Komunikat 2020b). Na początku epidemii pojawiały się kolejne zakażenia księży, zakonników oraz sióstr zakonnych w różnych diecezjach: przykładowo wikary z Łabuni (diecezja zamojsko-lubaczowska), proboszcz z Niskowa w diecezji tarnowskiej, ksiądz z diecezji koszalińsko-kołobrzeskiej, dominikanie w Rzeszowie - 22 marca. Nieco później skutki epidemii odczuły przykładowo również takie instytucje, jak pallotyńskie seminarium w Ołtarzewie, w którym 7 kwietnia 2020 r. stwierdzono sześć zakażeń, na początku maja - liczący 50 sióstr klasztor sióstr szarytek w Chełmnie, a na początku czerwca 134 redemptorystów oraz 12 czerwca Sekretariat Episkopatu Polski, który został zamknięty ze względu na zakażenie pięciu pracujących tam sióstr zakonnych. W wielu przypadkach wykrycie koronawirusa u księdza skutkowało zamykaniem kościołów oraz zakazem odprawiania mszy św.

Ograniczenie liczby osób uczestniczących w nabożeństwach stanowiło wyzwanie również z punktu widzenia prawnego. Artykuł 53 Konstytucji Rzeczpospolitej stwierdza, że 1) każdemu zapewnia się wolność sumienia i religii; 2) wolność religii obejmuje wolność wyznawania lub przyjmowania religii według własnego wyboru oraz uzewnętrzniania indywidualnie lub z innymi, publicznie lub prywatnie, swojej religii przez uprawianie kultu, modlitwę, uczestniczenie w obrzędach,

4 https://ekai.pl/pierwszy-w-polsce-przypadek-ksiedza-zakazonego-koronawirusem (dostęp: 18.05.2020). 
praktykowanie i nauczanie. Wolność religii obejmuje także posiadanie świątyń i innych miejsc kultu w zależności od potrzeb ludzi wierzących oraz prawo osób do korzystania z pomocy religijnej tam, gdzie się znajdują. Ponadto 3) nikt nie może być zmuszany do uczestniczenia ani do nieuczestniczenia w praktykach religijnych (Konstytucja 1997). Zgodnie z tymi zasadami organizacja praktyk religijnych należy do autonomicznej sfery wolności religijnej. Limity dotyczące praktyk religijnych nie były wyższe niż w innych miejscach, takich jak sklepy czy restauracje. W niektórych przypadkach naruszanie limitu osób obecnych w kościołach skutkowało nakładaniem na proboszczów mandatów ${ }^{5}$. Wyjątkowa sytuacja miała miejsce w Łowiczu 25 maja 2020 r. Policja zatrzymała pielgrzymów zdążających pieszo na Jasną Górę ${ }^{6}$. Odwołana została również zaplanowana na 6 czerwca w Warszawie ceremonia beatyfikacji kard. Stefana Wyszyńskiego.

Od 30 maja minister zdrowia zniósł limity osób przebywających w świątyniach, pozostawiając jedynie obowiązek noszenia maseczek. Podczas gdy w sierpniu liczba nowych zakażeń w Polsce zaczęła bić rekordy, propozycja ograniczenia liczby osób uczestniczących w liturgii nie była już brana pod uwagę przez rząd.

\section{Ograniczenie grupowych interakcji oraz więzi z parafią}

W ciągu ostatnich 30 lat polskie społeczeństwo podąża nieco odmiennym torem niż zachodnie kraje. O ile więc procesy religijne na Zachodzie można określić jako sekularyzacja, o tyle w Polsce przez ostatnie 30 lat mamy bardziej do czynienia z procesem, który można określić jako „indywidualizacja religijności”. Nie oznacza ona prostego trendu osłabienia religijnego, ale raczej złożony proces dynamicznego kształtowania się tożsamości religijnej Polaków w zmieniających się warunkach kulturowych. W polskim społeczeństwie przez ostatnie 20 lat niemal nie zmienił się odsetek Polaków, którzy uważają się za wierzących oraz nieznacznie wzrósł (do $8 \%)$ odsetek deklarujących się jako niewierzący. Polacy deklarują się jako osoby wierzące, jako katolicy. Jednocześnie religijność Polaków dynamicznie się zmienia. Zmiany te dotyczą przede wszystkim chodzenia co niedzielę do kościoła i przyjmowania komunii św. (Bożewicz 2020a).

$\mathrm{Z}$ niemal 60 do $47 \%$ zmniejszył się odsetek osób deklarujących regularne praktykowanie swojej wiary. Spadek następuje głównie od roku 2005. W tym też czasie odsetek osób deklarujących się jako niepraktykujący wzrósł do 15\% (tamże). Jak pokazują prowadzone od 40 lat regularne badania w tym zakresie od lat 80 ., gdy

\footnotetext{
5 https:/www.rmf24.pl/raporty/raport-koronawirus-z-chin/polska/news-czesc-ksiezy-nie-przestrzega -obostrzen-i-wpuszcza-do-kosciol,nId,4426635 (dostęp: 1.07.2020).

6 https://lowicz24.eu/artykul/policjanci-zatrzymali/1006094 (dostęp: 1.07.2020).
} 
wskaźnik dominicantes przekraczał 50\%, obserwujemy do początku lat 90 . wyraźny spadek nawet o kilkanaście punktów procentowych. W kolejnej dekadzie, czyli do początku XXI w., poziom niedzielnych praktyk Polaków utrzymywał się na względnie stabilnym poziomie - nieco ponad $45 \%$. Od roku około 2005 wskaźnik dominicantes regularnie spada (Sadłoń 2019). Spadek dominicantes w ostatnich latach dotyczy całego kraju - zarówno parafii miejskich, jak i wiejskich. Te wskaźniki mają odzwierciedlenie w deklaracjach Polaków (Bożewicz 2020a). Masowy charakter katolicyzmu w Polsce przejawia się również w przyjmowaniu sakramentów chrztu, pierwszej komunii św., bierzmowania (Sroczyńska 2013) oraz w ruchu pielgrzymkowym, który angażuje nawet kilkanaście procent Polaków. Badania stylów życia oraz spędzania wolnego czasu wskazują, że zanik praktyk religijnych Polaków wiąże się z zanikaniem więzi z parafią, spędzaniem większej ilości czasu wśród przyjaciół oraz przed telewizorem (Sadłoń i in. 2019, s. 29). Mamy do czynienia $z$ erozją tradycyjnych - szczególnie związanych z parafią - rytuałów religijnych. W latach 80 . w parafiach wiejskich aż 35\% mieszkańców uczęszczało na nabożeństwa majowe, $17 \%$ na nabożeństwa różańcowe, $34 \%$ na nabożeństwa Drogi Krzyżowej, a 20\% na nabożeństwa Gorzkich Żali. Bez wątpienia w parafiach wiejskich w przeszłości uczestnictwo w odpustach czy procesjach Bożego Ciała było znacznie bardziej popularne niż dzisiaj (Mariański 1983, s. 265-267).

Mimo tych zmian polski katolicyzm początku XXI w. cechuje wysoki poziom praktyk religijnych, co stanowi bez wątpienia przejaw ciągłości z tradycyjną pobożnością ludową (Mielicka-Pawłowska, Kochanowski 2014). W zachowaniu Polaków wciąż żywe są jednak tradycyjne formy pobożności, a ponadto pojawiają się nowe formy praktyk religijnych, które bez wątpienia stanowią kontynuację tradycyjnej religijności. W 2016 r. we wszystkich katolickich parafiach organizowane były nabożeństwa różańcowe, w co czwartej parafii $(23,4 \%)$ każdego dnia. $98 \%$ parafii organizowało nabożeństwa majowe (Sadłoń 2016c). W ostatnich dekadach popularne stało się nabożeństwo do Matki Bożej Fatimskiej, które praktykowane jest w 72\% parafii (tamże), oraz do Miłosierdzia Bożego związane z objawieniami św. Siostry Faustyny, które swoim zasięgiem objęło niemal cały powszechny katolicyzm. Osobnym zagadnieniem jest dynamika ruchu pielgrzymkowego w Polsce, który choć również bez wątpienia ulega zmianie w swoim natężeniu, kierunkach oraz charakterze, to jednak całkowicie nie zanika. Choć na poziomie jednostkowym związane ze świętami praktyki typowo religijne słabną, to jednak wciąż utrzymują się na wysokim poziomie. Przykładowo zachowywanie postu w Wielki Piątek w 2018 r. deklarowało 85\% Polaków (w 2006 r. 86\%), spowiedź w czasie Wielkanocy 67\% (w 2006 r. 79\%), posypywanie głowy popiołem - 64\% (w 2006 r. $71 \%$ ), natomiast uczestniczenie w liturgii wielkanocnej 56\% (w 2006 r. 65\%) (Głowacki 2018). 
Epidemia bez wątpienia dotyka jednego z najważniejszych aspektów polskiego katolicyzmu - związanego z praktykami religijnymi. Restrykcje wywołane zagrożeniem epidemicznym mocno ograniczyły tę formę aktywności polskiego katolicyzmu polegającą na wspólnotowych i masowych praktykach religijnych. Wyjście do kościoła pod koniec maja $2020 \mathrm{r}$ - - jak pokazały wyniki badania formy $4 \mathrm{P}$ - budziło obawę 38\% Polaków, czyli mniejszej części społeczeństwa niż na przykład wizyta w szpitalu (53\%) czy korzystanie z komunikacji zbiorowej (47\%), ale jednocześnie większej niż powrót do miejsca pracy (24\%) czy wizyta w sklepie (24\%). Częściej lęk przed przebywaniem wśród innych ludzi deklarowały kobiety, osoby młodsze oraz z wyższym wykształceniem. Szacunkowe dane wskazują, że udział katolików we mszy św. w pierwszą niedzielę po wprowadzeniu ograniczeń (15 marca) nie osiągał średnio nawet limitu 50 osób na kościół. 15 marca szacunkowy wskaźnik dominicantes wyniósł zaledwie $4 \%$. Po wprowadzeniu ograniczeń liczby osób w kościele do pięciu $27 \%$ badanych deklarowało, że uczestniczyło we mszy św., przy czym $18 \%$ kilka razy, $8 \%$ tylko raz, natomiast $1 \%$ choć próbowało, to „nie zmieściło się w dozwolonym limicie osób" (Bożewicz 2020b). Wśród tych, którzy nie byli w trakcie najbardziej restrykcyjnych ograniczeń w kościele, 27\% planowało pójść tam w najbliższym czasie (w tym 15\% w najbliższą niedzielę, a $12 \%$ w ciągu dwóch-trzech tygodni), natomiast $28 \%$ dopiero po ustaniu epidemii (w tym $17 \%$ po oficjalnym ogłoszeniu ustania epidemii, $11 \%$ zaś po całkowitym zdjęciu ograniczeń dotyczących liczby osób) (tamże).

Epidemia wtłoczyła przede wszystkim życie parafialne w swoisty gorset. Ograniczając swobodę interakcji oraz organizowania duszpasterstwa, niejako wzmocniła obserwowany od roku 2000 proces zanikania więzi z parafią. Spoglądając w dalszej perspektywie, epidemia bez wątpienia ograniczy swobodę prowadzenia wizyty duszpasterskiej, czyli tzw. kolędy, która stanowiła istotny przejaw budowania więzi z parafią, szczególnie w społecznościach wiejskich. Przykładowo w 2006 r. jedynie $2 \%$ badanych mieszkańców diecezji radomskiej deklarowało, że nie przyjmuje kolędy. W diecezji bydgoskiej w 2008 r. aż 83\% mieszkańców deklarowało, że przyjmuje księdza „po kolędzie” co roku (Zdaniewicz, Zaręba 2008). Epidemia redukuje nagromadzony wokół parafii kapitał społeczny. Już wcześniej miał on charakter przede wszystkim wsobny (bonding), czyli w pewnym sensie zamknięty, nie zaś pomostowy (bridging), który byłby w stanie łączyć ludność ponad podziałami społecznymi (Sadłoń 2014a). Epidemia mocno ogranicza tzw. behawioralną więź katolików ze swoją parafią, która szczególnie na wsi stanowiła istotny aspekt funkcjonowania społeczności lokalnej (Sadłoń 2019). Ograniczenie interakcji w parafii stwarza również zagrożenie dla finansowej płynności parafii, gdyż jej przychody pochodzą $w$ zdecydowanej części $z$ dobrowolnych ofiar wiernych, w tym za sprawowane sakramenty (Sadłoń 2016c). 
Jak wynika z zapisków osób prowadzących dzienniki, epidemia wzbudziła poczucie niepokoju wśród duszpasterzy w parafiach. Zrodziło się przekonanie o wyjątkowości sytuacji. Szczególnie świadomość przeżywania zbliżających się świąt wielkanocnych w rygorze sanitarnym budziła emocje. Księża z lękiem obserwowali, jak bardzo wierni ograniczyli przychodzenie do kościoła. W zapiskach duszpasterzy przebija się zdziwienie, że na mszę św. przychodzą niemal wyłącznie osoby, które zamówiły intencję, a czasem nawet i one się nie pojawiają. W późniejszym czasie duszpasterze zaczęli dostrzegać, że do kościoła chodzą osoby najbardziej zaangażowane. W miastach duszpasterze troszczyli się również o to, aby w kościele nie przebywało więcej osób, niż określają przepisy. Dlatego np. kościelny po prostu zamykał drzwi świątyni, gdy znalazła się już w niej dopuszczalna liczba osób. Zdziwienie budziło również wymaganie noszenia maseczki w kościele, o czym świadczy poniższa wypowiedź zapisana 16 kwietnia w dzienniku duszpasterza $\mathrm{z}$ archidiecezji łódzkiej:

To naprawdę przedziwne, że trzeba jednak nosić te maseczki. Nie jest to ani specjalnie wygodne, ani komfortowe. Poza tym w przestrzeni sakralnej wygląda to doprawdy dziwnie. A przecież trzeba też wziąć pod uwagę fakt, że nikt dzisiaj nie umie przewidzieć, jak długo będzie trzeba je na sobie mieć [...] Musimy się jednak podporządkować.

Jak więc wynika z powyższej oraz też innych wypowiedzi, duszpasterze stosowali się do zaleceń dotyczących bezpieczeństwa. Jednocześnie z ulgą przyjmowali kolejne łagodzenie limitów oraz ograniczeń.

Relacje księży z wiejskich parafii wskazują na znacznie większy spokój i opanowanie, z czym kontrastują zmęczenie i chaos panujące w miastach. Świadczy o tym przykładowo krótka charakterystyka poszczególnych wydarzeń w życia duszpasterza wiejskiej parafii z diecezji tarnowskiej:

Po Jutrzni idę do sklepu po pieczywo. Sklep blisko naszego domu 2 min. na pieszo. W sklepie obecni tylko właściciele, pan $\mathrm{N}$ z żoną, oraz jedna pani kupująca przede mną. Krótka rozmowa z panem N, który stwierdza, że inne to będą Święta w tym roku (10 kwietnia 2020 r., duszpasterz z diecezji tarnowskiej, parafia wiejska).

Kontrastuje z tym wypowiedź duszpasterza parafii miejskiej z archidiecezji łódzkiej:

Wieczorem byłem zaś bardzo zmęczony całym dniem: właściwie cały czas byłem na nogach, i pod koniec dnia „odłączyło mi prąd”. Jednak odprawienie kilku Mszy 
Świętych jednego dnia, do tego udzielanie sakramentu spowiedzi, nagrywanie nabożeństw plus „zwykłe” codzienne modlitwy kapłana potrafią wyssać z człowieka wiele sił [...] (19 kwietnia 2020 r., duszpasterz z archidiecezji łódzkiej).

Zmęczenie księży wynikało z nowych wyzwań duszpasterskich, jakie się pojawiły. Uruchamiali oni transmisje mszy św. w internecie, poprawiali nagłośnienie wokół kościoła, aby wierni mogli uczestniczyć we mszy, nie wchodząc do świątyni. Ponadto wyzwaniem było też podejmowanie decyzji związanych z dostosowaniem sprawowania liturgii do aktualnej sytuacji i wymogów sanitarnych. Przejawem takiego dostosowania było rozdawanie komunii św. w drzwiach wejściowych do kościoła i umożliwienie wiernym indywidualnej spowiedzi. Niektórzy duszpasterze dodatkowo nagrywali swoje wypowiedzi i komentarze oraz umieszczali nagrania $\mathrm{w}$ internecie. $\mathrm{W}$ poszukiwaniu kontaktu $\mathrm{z}$ wiernymi dostrzegali wyraźnie rolę internetu oraz mediów.

W ten sposób epidemia wyraźnie zmieniła relacje pomiędzy księżmi i wiernymi. Niektórzy duszpasterze starali się nawiązać bardziej bezpośredni kontakt z wiernymi, podając im na przykład swój prywatny numer telefonu czy też zapraszając do korzystania ze spowiedzi na plebanii. Z lektury uzyskanych dzienników wyłania się obraz, jakoby w czasie epidemii na wsi duszpasterze mogli liczyć na większą pomoc wiernych. Świadczy o tym choćby takie wspomnienie z dziennika duszpasterza $\mathrm{z}$ wiejskiej parafii diecezji tarnowskiej:

Piszę dalej relację, następny telefon, od pani N z Rady Parafialnej, czy zgadzam się, aby jeszcze dzisiaj przeciągnąć kabel z Routera na plebanii do zakrystii w kościele, aby poprawić jakość transmisji na stronie parafialnej. Zgadzam się. Za chwilę kolejny telefon od pani, która pomaga nam w sprawach ZUS, aby złożyć wniosek o zwolnienie ze składek dla księży i pracowników. Złożymy (10 kwietnia 2020 r.).

Z takiej perspektywy reżim społeczny związany z epidemią bez wątpienia wtłoczył polski katolicyzm $\mathrm{z}$ dodatkową ramę, która wzmacnia procesy obserwowane na zachodzie Europy. Z drugiej jednak strony dynamika polskiego katolicyzmu nie ogranicza się wyłącznie do zbiorowych praktyk religijnych w świątyniach. Najważniejszą wartością w życiu Polaków jest rodzina. Ponad 80\% deklaruje przywiązanie do rodziny. (Sobestjański, Bieńkuńska 2017, s. 92). Rodzina stanowi podstawowe źródło szczęścia Polaków. W 2013 r. 85\% Polaków deklarowało, że „każdy potrzebuję rodziny”, aby być szczęśliwym (Boguszewski 2013, s. 3). W jej funkcjonowaniu coraz większe znaczenie ma czas wolny, osobiste zainteresowania oraz potrzeby jednostkowe, a tracą na nim wartości związane $\mathrm{z}$ zaangażowaniem 
społecznym (Świątkiewicz 2013). Nastawienie wobec rodziny wyraźnie koreluje z religijnością (Hipsz 2013, s. 7). Tradycyjne praktyki o charakterze religijnym mocno wpisane są w funkcjonowanie gospodarstw domowych (katolickich rodzin). Ponad 90\% Polaków deklaruje kultywowanie tradycji Bożego Narodzenia oraz Wielkanocy, takich jak tzw. opłatek czy święconka. Jednocześnie wyraźnie zmienia się charakter przeżywania świąt. Jak wskazują wyniki badań, przede wszystkim święta Bożego Narodzenia i Wielkanocy tracą charakter religijny, a jednocześnie stają się coraz bardziej świętami rodzinnymi. Polacy traktują tradycyjne religijne święta coraz częściej jako okazję do spotkania w rodzinie, a coraz rzadziej jako manifestację religijnej wiary (Feliksiak 2019).

Sondaż przeprowadzony przez ISKK we współpracy z portalem Onet.pl wykazał, że w czasie epidemii czytelnicy tego medium najczęściej mogą liczyć na pomoc rodziny (aż 81\%). Jedynie 36\% zadeklarowało, że może liczyć na pomoc sąsiedzką, $15 \%$ na pomoc lokalnych władz, 17\% - służb publicznych, $8 \%$ - organizacji kościelnych. Z kolei dzienniki ukazały, że chociaż epidemia bez wątpienia osłabiła zwykłe interakcje w parafiach, to jednak wzmocniła interakcje w obrębie gospodarstw domowych. W tym czasie rodziny podejmowały więcej wspólnej aktywności. Szczególnie święta wielkanocne zmotywowały ludzi do skupienia się na relacjach rodzinnych. Wskazuje na to decyzja rodziny z archidiecezji krakowskiej:

Wspólnie z [żoną] postanowiliśmy, że dla właściwego przeżycia Triduum Paschalnego rezygnujemy z korzystania z mediów elektronicznych, z wyjątkiem udziału w uroczystościach religijnych, rekolekcjach, działaniach zawodowych lub modlitwach. Mimo wszystko będzie to wyzwanie. Szczególnie teraz odczuwamy, jak mocno nasza rzeczywistość przesiąknięta jest elektroniką i mediami (9 kwietnia 2020 r., osoba świecka, archidiecezja krakowska).

Wydaje się, że dynamika polskiego katolicyzmu nie opiera się wyłącznie na swoistym społecznym habitusie, czyli powtarzalnych zachowaniach, które ogranicza w sposób niemal mechaniczny epidemia. Poziom oglądalności transmisji nabożeństw w mediach dowodzi, że w znacznej mierze praktyki religijne w czasie kwarantanny przeniosły się z kościołów do domów. 15 marca, czyli w pierwszą niedzielę po wprowadzeniu restrykcji dotyczących obecności w kościołach, mszę św. o godz. 7 oglądało 1,438 mln osób na kanale TVP1 oraz 0,452 mln na kanale TVP Info. Mszę św. o godz. 11 na kanale TVP1 oglądało 2,265 mln widzów, natomiast o godz. 9 na kanale Polsat News - 0,731 mln widzów. Msze św. transmitowane były również $\mathrm{w}$ internecie oraz poprzez radio. $\mathrm{W}$ kolejnych tygodniach epidemii poszczególne parafie uruchamiały także własne transmisję mszy św. w internecie. Przykładowo poprzez kanał YouTube Archidiecezji Warszawskiej z kościoła 
seminaryjnego Wniebowzięcia NMP i św. Józefa Oblubieńca w Warszawie mszę św. 15 marca 2020 r. o godz. 11 oglądało 43664 osób. Tydzień później, czyli 22 marca 2020 r. - 23 482, natomiast 29 marca - 36701 . W kolejne niedziele transmisja internetowa mszy św. o godz. 11 z tego kościoła przyciągała kolejno: 35598 (5 kwietnia), 25267 (12 kwietnia), 45247 (19 kwietnia) oraz 30593 widzów (26 kwietnia).

\section{Wpływ epidemii na proces dyferencjacji polskiego katolicyzmu}

Taylorowska kategoria immanentnej ramy wydaje się mieć zastosowanie również do analizy przemian polskiego katolicyzmu. Transformacja polskiego społeczeństwa w ciągu ostatnich 30 lat przejawia się m.in. w poprawie jakości życia Polaków. Od 1990 r. stopniowo wzrastają jego subiektywne wskaźniki. Od 2003 r. stopniowo coraz mniej Polaków deklaruje problemy zdrowotne. Wzrasta również satysfakcja z własnego zdrowia (Czapiński 2015, s. 231). Mimo że przy kontroli wieku poziom zaangażowania religijnego oraz poczucie satysfakcji z życia są pozytywnie ze sobą skorelowane (Bieńkuńska, Piasecki 2020), to subiektywna jakość życia Polaków związana jest raczej ze zdrowiem i jakością relacji międzyludzkich niż z religią. Ponadto traktowanie pieniędzy oraz Boga jako wartości w życiu wyraźnie kontrastują ze sobą (Feliksiak 2017, s. 5; Czapiński 2015, s. 256). Świadczy to o swoistej wzrastającej „immanentnej” orientacji polskiego społeczeństwa. Jednocześnie w ramach takiego ogólnego procesu ujawniają się trendy, które mają znacznie węższy zasięg, ale które wyraźnie oddziałują na polski katolicyzm. Polskie społeczeństwo, w tym również katolicyzm, podlega nie tylko jednowymiarowym procesom indywidualizacji, lecz również wyrazistym procesom wewnętrznej dyferencjacji (Sadłoń 2016b). O ile wyraźnie rośnie dystans do instytucji Kościoła mierzony m.in. poziomem zaufania, które po 2010 r. osiąga najniższe od 1990 r. poziomy, o tyle można mówić o rosnącej „katolickiej integralności” pewnej części polskiego społeczeństwa.

Jednym z najbardziej istotnych procesów zachodzących w ostatniej dekadzie w polskim katolicyzmie jest spadek religijności najmłodszego pokolenia. W roku 2018 polskie społeczeństwo na tle 44 innych krajów Europy i świata charakteryzowało się najwyższym „rozstępem” pomiędzy religijnością starszego i młodszego pokolenia. Podczas gdy średnia różnica pomiędzy religijnością osób poniżej i powyżej 40 roku życia w Europie wynosiła 7 punktów procentowych, to w Polsce osiągała poziom 16 punktów (Pew Research Center 2018). Od 1988 r. w młodszym pokoleniu obserwuje się niezmienne przekonanie, że jego religijność słabnie (Sadłoń 2020a).O ile w pierwszych dekadach po 1989 r. odsetek osób uczestniczących w lekcjach religii wzrastał: od $81 \%$ w 1991 r. do $93 \%$ w 2010, o tyle od 2010 r. wyraźnie się zmniejsza. W 2018 r. 70\% młodzieży uczestniczyło w publicznych lekcjach religii (Grabowska, Gwiazda 2019, s. 162-165). Zróżnicowanie pod tym 
względem widać również na wsi i w miastach. W Warszawie już w 2003 r. nie więcej niż 75\% młodzieży deklarowało udział w lekcjach religii (Zaręba 2006, s. 256). Chociaż środowisko wiejskie bez wątpienia charakteryzuje się wyższą religijnością, to młodzież pochodząca ze wsi, gdy trafia do miasta, nie różni się pod względem religijnym od swoich rówieśników pochodzących z miasta (Sadłoń 2020a). Dowodzi to znów roli rodziny oraz faktu, że socjalizacja religijna w Polsce realizuje się przede wszystkim w rodzinie. Ta dynamika religijności najmłodszego pokolenia wskazuje już na daleko posunięte zróżnicowanie religijności polskiego społeczeństwa oraz bardziej złożone dynamizmy kształtujące polski katolicyzm niż tylko "globalne” i jednokierunkowe procesy.

$Z$ drugiej strony od 20 lat nie zmniejszył się odsetek młodzieży deklarującej się jako głęboko wierząca (Sadłoń 2020). Od roku 1980 do 2000 odsetek osób przyjmujących komunię św. regularnie wzrastał z niespełna 8 do 17\%, a w ostatnich dwóch dekadach utrzymuje się na względnie stabilnym poziomie. W ostatnich dekadach wzrastał również odsetek katolików należących do przyparafialnych małych grup religijnych (tzw. wskaźnik participantes)(Sadłoń 2014b). W 1993 r. jedynie 4,3\% katolików należało do takich grup, a po 20 latach niemal dwukrotnie więcej - 8\% (tabela 2). Oznacza to, że niemal 2,7 mln katolików aktywnie uczestniczy w grupach modlitewnych, formacyjnych lub charytatywnych.

Tabela 2. Participantes w latach 1993-2018

Table 2. Participants between 1993 and 2018

\begin{tabular}{cc}
\hline Rok & Participantes (w \%) \\
\hline 1993 & 4,3 \\
1998 & 6,2 \\
2003 & 7,8 \\
2008 & 7,9 \\
2013 & 8,0 \\
2018 & 8,1 \\
\hline
\end{tabular}

Źródło: Sadłoń, Organek 2019.

Source: Sadłoń and Organek 2019.

W tym czasie prawie podwoiła się liczba małych grup duszpasterskich w polskich parafiach katolickich z 39,6 tys. do ponad 60 tys. (Sadłoń, Kazanecka 2016). Dyferencjacja polskiego katolicyzmu przejawia się również w mobilizacji związanej z koncepcją tzw. nowej ewangelizacji. W latach 2003-2016 liczba tzw. szkół nowej ewangelizacji zwiększyła się z 50 do 360, natomiast liczba osób w nich 
zaangażowanych wzrosła z 5 tys. do 60 tys. (Szlachetka 2012) ${ }^{7}$. Badanie budżetu czasu Głównego Urzędu Statystycznego wykazało, że chociaż w latach 20032013 odsetek osób deklarujących praktyki religijne zmniejszył się z 19,7 do 16,2\%, to średni czas przeznaczany na ich wykonywanie wzrósł (GUS 2025). O swoistym krystalizowaniu się „integralnej” mniejszości katolików w Polsce może świadczyć również rosnące sprzężenie religijności z akceptacją katolickiego nauczania moralnego w kwestii aborcji (Frątczak, Sikorska 2009). Od 1989 r. wzrasta również statystyczna zależność pomiędzy religijnością a poglądami politycznymi (Rosta 2014).

W takiej perspektywie dyferencjacji epidemia koronawirusa oddziałuje więc nie tylko globalnie na polskie społeczeństwo, ale również na wewnętrzne zróżnicowanie katolicyzmu jako systemu społeczno-kulturowego. Dostrzec to można już na poziomie samych instytucjonalnych reakcji biskupów na epidemię. We wspomnianym już dokumencie z 28 lutego przewodniczący Konferencji Biskupów abp Stanisław Gądecki przypomniał, że w tradycję katolicką wpisana jest praktyka przyjmowania komunii św. w sposób mistyczno-duchowy. Komisja Stała Episkopatu $\mathrm{w}$ dokumencie z 12 marca wprowadzającym ograniczenia w liturgii bardzo wyraźnie podkreślała, że nie oznaczają one zawieszenia życia religijnego w parafiach: „tak jak szpitale leczą choroby ciała, tak kościoły służą m.in. leczeniu chorób ducha, dlatego jest niewyobrażalne, abyśmy nie modlili się w naszych kościołach", oraz „Kościół od dwóch tysiącleci służy osobom chorym i potrzebującym, nawet w czasach epidemii, nie rezygnując z głoszenia Ewangelii oraz sprawowania sakramentów świętych". Biskupi zachęcali również do solidarności, szczególnie z osobami starszymi. W ten sposób wyraźnie starali się dostosować zachowania religijne do wymogów bezpieczeństwa, jednocześnie zapewniając ciągłość życia modlitewnego i duchowego. W zaleceniach biskupów nie brakło więc apelu o żarliwą modlitwę:

Prosimy wszystkich ludzi wierzących o modlitwę w intencji ochrony przed chorobami, a także o pokój serc i łaskę głębokiego nawrócenia dla każdego $\mathrm{z}$ nas. Dobremu Bogu polecajmy wszystkich zmarłych na skutek koronawirusa. Módlmy się o zdrowie dla chorych, tych, którzy się nimi opiekują, lekarzy i personelu medycznego oraz wszystkich służb sanitarnych. Módlmy się o wygaśnięcie epidemii. Zgodnie z Tradycją Kościoła zachęcamy do śpiewania w naszych kościołach suplikacji „Święty Boże, Święty Mocny... Od powietrza, głodu, ognia i wojny, zachowaj nas Panie".

Instytucjonalna reakcja Kościoła katolickiego na epidemię zawierała również próbę jej interpretacji w kategoriach teologicznych oraz umożliwienia przeżywania

7 Zob. także dane Zespołu ds. Nowej Ewangelizacji Konferencji Episkopatu Polski. 
zbliżającej się Wielkanocy w duchu katolickim. W sobotę 14 marca abp Stanisław Gądecki wygłosił orędzie telewizyjne transmitowane przez TVP1, TVP Info, TVN24, Polsat News, TV Trwam oraz Onet, w którym nawiązał do trwającego Wielkiego Postu oraz zwrócił uwagę na przygodność oraz bezsilność człowieka:

Do niedawna wydawało się nam, iż postęp techniczny, wiara w nieograniczoną ludzką wolność, w nieomylność demokracji zbuduje nowy raj na ziemi, w którym nie będzie ani chorób, ani cierpienia. A oto z pokorą odkrywamy, że wystarczy jedna pandemia, by okazało się, jak bezbronnym i przerażonym wobec niej staje się człowiek (Orędzie 2020a).

16 marca bp Romuald Kamiński, przewodniczący Zespołu ds. Służby Zdrowia KEP, podziękował pracownikom służby zdrowia oraz zapewnił o solidarności i duchowym wsparciu dla personelu medycznego (List 2020b).

1 kwietnia Komisja Nauki Wiary Konferencji Episkopatu Polski wydała notę, w której podjęła się interpretacji duchowej sytuacji w czasie epidemii. W dokumencie zwrócono uwagę na doświadczenie lęku, jakie wywołuje epidemia, na rolę wiary w rozbudzaniu nadziei, na teologiczną interpretację historii w kategorii znaków czasu oraz na duchową solidarność w obliczu epidemii. Dokument przestrzega również przed propagowaniem „fałszywej historiozofii, powoływanie[m] się na prywatne pseudoobjawienia i sny" oraz lekceważeniem zasad bezpieczeństwa w kościołach (Nota 2020) i krytykuje „magiczne traktowanie sakramentów i sakramentaliów, promowanie wizji Kościoła jako bezpiecznej arki, przeznaczonej wyłącznie dla świętych i sprawiedliwych”. 2 kwietnia Komisja ds. Kultu Bożego i Dyscypliny Sakramentów Konferencji Episkopatu Polski wydała komunikat, w którym wyjaśniła, że duchowe owoce praktyki pierwszych piątków oraz pierwszych sobót miesiąca ze względu na fizyczną niemożliwość spowiedzi oraz przyjmowania komunii św. „nie zostają przerwane” (Komunikat 2020c). 4 kwietnia przewodniczący Episkopatu Polski wygłosił drugie przemówienie telewizyjne, w którym nawiązał do teologicznego znaczenia Wielkiego Tygodnia i w perspektywie paschalnej zinterpretował czas epidemii, zwracając uwagę na wywołane nią cierpienie oraz samotność. Wyjaśnił również, w jaki sposób katolicy w Polsce mogą uczestniczyć w sakramentach w sposób duchowy, oraz zachęcił do solidarności (Orędzie 2020b). Warto również dodać, że Orędzie przewodniczącego Episkopatu w dniu 4 kwietnia 2020 r. było transmitowane przez kanały TVP1 oraz TVP Info i przyciągnęło $3,9 \mathrm{mln}$ osób $^{8}$.

\footnotetext{
8 https://www.tvp.pl/centrum-informacji/informacje-dla-mediow/komunikaty-centrum-informacji/ 4-kwietnia-tvp1-i-tvp-info-najpopularniejszymi-antenami/47446306 (dostęp: 1.07.2020).
} 
Z zapisków w prowadzonych dziennikach wynika, że epidemia wzmaga refleksję nad życiem w kategoriach duchowych. Zarówno księża, jak i osoby świeckie głęboko teologicznie interpretują to wydarzenie. Odwołują się w tym szczególnie do objawień prywatnych. Świadczy o tym wypowiedź duszpasterza z archidiecezji łódzkiej:

Im dłużej bowiem trwa epidemia, tym częściej słyszę od moich parafian: o tym, co teraz się dzieje, mówiła Matka Boża w objawieniach z Trevignano Romano9. Jak wiadomo, objawienia te nie są uznane przez Kościół; podobnie jak szereg innych objawień i cudownych wizji. Jednak moi wierni - przynajmniej niektórzy - zdają się bardzo mocno wierzyć w treść rzekomych objawień np. właśnie z Trevignano (11 kwietnia 2020 r., duszpasterz z archidiecezji łódzkiej).

Osobną kwestią, która skupia uwagę, jest przyjmowanie komunii św. w czasie epidemii. Zarówno wierni, jak i duszpasterze stanęli przed dylematem przyjmowania komunii św. na rękę lub do ust. Księża zwracają uwagę, że znaczna część wiernych nie stosuje się do apelu księży biskupów i nie chce przyjmować komunii św. na rękę.

Według wyników badania Centrum Badania Opinii Społecznej pomiędzy 22 maja a 4 czerwca 75\% Polaków oceniło, że ich zaangażowanie religijne nie zmieniło się w okresie społecznej kwarantanny. $12 \%$ wskazało, że więcej czasu poświęcili na modlitwę, medytację oraz inne praktyki religijne. Jedynie $3 \%$ nie potrafiło ocenić poziomu zmiany własnej religijności. Wyniki tego samego badania wskazują, że w czasie pandemii $60 \%$ badanych oglądało transmisję mszy św. w telewizji, $21 \%$ przez internet, a $17 \%$ w radiu. $20 \%$ badanych modliło się np. na różańcu, w łączności z innymi (przez internet, radio, telewizję). Z kolei 40\% miało odczucie, że brakuje im wspólnotowej modlitwy w kościele, a 11\% chodziło do świątyni na modlitwę (Bożewicz 2020b). Badanie przeprowadzone w dniach od 11 do 14 kwietnia 2020 r. wśród czytelników portalu Onet.pl po odpowiedniej kalibracji uwzględniającej rozkłady cech demograficznych dla ogółu polskiego społeczeństwa wykazało, że $16 \% \mathrm{z}$ nich w czasie epidemii więcej się modli, $27 \%$ planowało oglądać transmisję nabożeństw religijnych w czasie epidemii, 32\% wyraziło żal, że nie będzie mogło poświęcić pokarmów w kościele. $88 \%$ spośród czytelników Onet.pl uważa, że pandemia pokazała, że człowiek jest bezradny wobec natury, 50\% zadeklarowała, że w czasie epidemii więcej myśli o sensie życia. Częściej o sensie życia w czasie epidemii myślą ludzie młodzi. Te dane mogą świadczyć, że epidemia będzie pogłębiać proces wewnętrznego różnicowania się religijności

9 Domniemane objawienia Matki Bożej w małej miejscowości położonej niedaleko Rzymu we Włoszech, w których Maryja miała przepowiedzieć epidemię koronawirusa. 
w obrębie polskiego katolicyzmu. 37\% czytelników Onet.pl twierdziło, że wiara w Boga pomaga przeżyć czas epidemii. Częściej uważali tak ludzie młodzi oraz $\mathrm{w}$ dużych miastach.

\section{Podsumowanie}

Przeprowadzona powyżej wstępna i dość pobieżna analiza pozwala na wyciągnięcie kilku jednoznacznych wniosków. Epidemia nałożyła na polski katolicyzm swoistą formę, która ograniczyła zasięg interakcji oraz praktyk zbiorowych. W ten sposób stanowi ona swoistą ramę, która wzmacnia obserwowany przynajmniej od dwóch dekad proces słabnięcia religijnych praktyk zbiorowych oraz więzi z parafią. Tym samym zmniejsza systemową spójność polskiego katolicyzmu poprzez osłabienie masowych praktyk oraz aktywności zbiorowej, takich jak uroczystości religijne czy pielgrzymki.

Jednocześnie przedstawione wyniki badań na tle wiedzy o dynamice polskiego katolicyzmu pozwalają sądzić, że epidemia wzmacnia kluczowe dla polskiego katolicyzmu powiązanie więzi rodzinnych oraz religijności. Wyraźnie wzmacnia ona również inny proces obserwowany w obrębie polskiego katolicyzmu - dyferencjacji. Epidemia dla części społeczeństwa stanowi doświadczenie teologizujące, które otwiera na szukanie transcendencji i znajdowania odpowiedzi na te duchowe potrzeby w katolicyzmie i $w$ ten sposób może spotęgować proces różnicowania się postaw religijnych Polaków. Oznacza to, że chociaż epidemia jako forma społeczna jest swoistą ramą, która ogranicza polski katolicyzm, to jednocześnie generuje reakcje, które uruchamiają procesy przeciwne zamykaniu się w immanentnej ramie opisanej przez Charlesa Taylora.

\section{Bibliografia}

Archer M. (1988). Culture and Agency. The Place of Culture in Social Theory. Cambridge: Cambridge University Press.

Archer M. (1995). Realist Social Theory. Cambridge: Cambridge University Press.

Archer M. (2000). Being Human: The Problem of Agency. Cambridge: Cambridge University Press.

Baker J.O., Perry S.L., Whitehead A.L. (2020). Crusading for moral authority: Christian nationalism and opposition to science. Sociological Forum, doi: 10.1111/socf.12619.

Bieńkuńska A., Piasecki, T. (2020). Religijność a dobrobyt subiektywny na podstawie Badania spójności społecznej z $2018 \mathrm{r}$. W: P. Ciecieląg (red.). Wyznania religijne w Polsce 2015-2018 (s. 359-371). Warszawa: Główny Urząd Statystyczny.

Boguszewski R. (2013). Komunikat z badań: Rodzina - jej wspó́czesne znaczenie i rozumienie, $B S / 33$. Warszawa: Centrum Badania Opinii Społecznej. 
Bożewicz M. (2020a). Komunikat z badań: Religijność Polaków w ostatnich 20 latach. Warszawa: Centrum Badania Opinii Społecznej.

Bożewicz M. (2020b). Wpływ pandemii na religijność Polaków. Komunikat CBOS 74/2020. Warszawa: Centrum Badania Opinii Społecznej.

Czapiński J. (2015). Indywidualna jakość i styl życia. W: J. Czapiński, T. Panek (red.). Diagnoza społeczna 2015. Warunki i jakość życia Polaków (s. 183-313). Warszawa: Rada Monitoringu Społecznego.

Dekret (2020). Dekret Kongregacji ds. Kultu Bożego i Dyscypliny Sakramentów W czasie Covid-19 z dnia 21 marca 2020 r., https://episkopat.pl/watykan-o-celebrowaniu-wielkanocy-w-czasie-epidemii-2/ (dostęp: 1.07.2020).

Feliksiak M. (2017). Komunikat z badań: Sens życia - wczoraj i dziś. Warszawa: Centrum Badania Opinii Społecznej.

Feliksiak M. (2019). Więzi rodzinne. Warszawa: Centrum Badania Opinii Społecznej.

Frątczak E., Sikorska I. (2009). Changing attitudes and behaviour concerning contraception and abortion in Poland. Studia Demograficzne, 156, 73-114.

Głowacki A. (2018). Komunikat z badań: Wielkanoc 2018. Warszawa: Centrum Badania Opinii Społecznej.

Grabowska G., Gwiazda M. (2019). Młodzież 2018. Warszawa: Centrum Badania Opinii Społecznej.

GUS (2025). Budżet czasu ludności 2013. Część I. Warszawa: Główny Urząd Statystyczny.

Hill T.D., Gonzalez K., Burdette A.M. (2020). The blood of Christ compels them: State religiosity and state population mobility during the coronavirus (covid-19) pandemic. Journal of Religion and Health, https://doi.org/10.1007/s10943-020-01058-9.

Hipsz N. (2013). Komunikat z badań: Społeczne oceny alternatyw życia małżeńskiego. Warszawa: Centrum Badania Opinii Społecznej.

Komunikat (2020a). Komunikat Przewodniczącego Konferencji Episkopatu Polski z dnia 13 marca 2020 r., https://episkopat.pl/przewodniczacy-episkopatu-stosujmy-sie-rozporzadzenia-organow-panstwowych-by-na-mszy-sw-w-kosciolach-przebywalo-do-50-osob-2/ (dostęp: 26.08.2020).

Komunikat (2020b). Komunikat Przewodniczącego Konferencji Episkopatu Polski w sprawie dyspens od udziału w niedzielnych mszach świętych z dnia 27 maja 2020 r., https:// episkopat.pl/komunikat-przewodniczacego-konferencji-episkopatu-polski-ws-dyspens -od-udzialu-w-niedzielnych-mszach-swietych/ (dostęp: 1.07.2020).

Komunikat (2020c). Komunikat Komisji ds. Kultu Bożego i Dyscypliny Sakramentów KEP Praktyka pierwszych piątków i pierwszych sobót miesiąca w okresie epidemii z dnia 2 kwietnia 2020 r., https://episkopat.pl/komunikat-komisji-ds-kultu-bozego-i-dyscypliny-sakramentow-kep-praktyka-pierwszych-piatkow-i-pierwszych-sobot -miesiaca-w-okresie-epidemii/ (dostęp: 1.07.2020).

Konstytucja (1997). Konstytucja Rzeczypospolitej Polskiej, Dz.U. z 1997 r. Nr 78, poz. 483. List (2020a). List Przewodniczącego KEP do Premiera o proporcjonalne kryterium ustalania liczby wiernych w kościele z dnia 15 kwietnia 2020 r., https://episkopat.pl/przewodniczacy-kep-apeluje-o-proporcjonalne-kryterium-ustalania-liczby-wiernych-w -kosciele-2/ (dostęp: 1.07.2020). 
List (2020b). List bp. Romualda Kamińskiego do pracowników służby zdrowia z dnia 16 marca 2020 r., https://episkopat.pl/list-bp-romualda-kaminskiego-do-pracownikow-ochrony-zdrowia/ (dostęp: 1.07.2020).

Mariański J. (1983). Religijność ludowa na wsi. W: W. Piwowarski (red.), Wprowadzenie. Religijność ludowa. Ciaggłość i zmiana (s. 241-280). Wrocław: Wydawnictwo Wrocławskiej Księgarni Archidiecezjalnej.

McDaniel E.L., Nooruddin I., Shortle A.F. (2011). Divine boundaries: How religion shapes citizens' attitudes toward immigrants. American Politics Research, 39 (1), 205-233.

Mielicka-Pawłowska H., Kochanowski J. (2014). Religioeses Brauchtum der Polen. W: E. Firlit, M. Hainz, M. Libiszowska-Zoltkowska, G. Pickel, D. Pollack (red.). Zwischen Saekularisierung und religioeser Vitalisierung. Religiositaet in Deutschland und Polen im Vergleich (s. 257-270). Wiesbaden: Springer.

Nota (2020). Nota Komisji Nauki Wiary Konfrencji Episkopatu Polski w związku z pandemią koronawirusa $\mathrm{z}$ dnia 1 kwietnia 2020 r., https://episkopat.pl/nota-komisji-nauki-wiary-konferencji-episkopatu-polski-w-Zwiazku-z-pandemia-koronawirusa/ (dostęp: 1.07.2020).

Orędzie (2020a). Orędzie telewizyjne Przewodniczącego Konferencji Episkopatu Polski z dnia 14 marca 2020 r., https://episkopat.pl/abp-gadecki-zachecam-do-korzystania-z-dyspensy-od-uczestnictwa-w-niedzielnej-mszy-sw-2/ (dostęp: 26.08.2020).

Orędzie (2020b). Orędzie telewizyjne Przewodniczącego Konferencji Episkopatu Polski z dnia 4 kwietnia 2020 r., https://episkopat.pl/oredzie-telewizyjne-przewodniczacego -konferencji-episkopatu-polski-4-kwietnia-2020-r/ (dostęp: 1.07.2020).

Oświadczenie (2020). Oświadczenie Rady ds. Społecznych Konferencji Episkopatu Polski: Czas odpowiedzialności, solidarności, sprawiedliwości z dnia 26 marca 2020, https:// episkopat.pl/rada-ds-spolecznych-episkopatu-o-potrzebie-odpowiedzialnosci-solidarnosci-i-sprawiedliwosci-2/ (dostęp: 1.07.2020).

Perry S.L., Whitehead A.L., Joshua B., Grubbs J.B. (2020). Culture wars and COVID-19 conduct: Christian nationalism, religiosity, and Americans' behavior during the coronavirus pandemic. Journal for the Scientific Study of Religion, https://doi.org/10.1111/jssr.12677.

Pew Research Center (2018). The Age Gap in Religion Around the World, https://www.pewforum.org/2018/06/13/the-age-gap-in-religion-around-the-world/ (dostęp: 18.06.2020).

Rosta G. (2014). Religiosität und politische Präferenzen - Polen und Deutschland. W: M. Hainz (red.). Zwischen Säkularisierung und religiöser Vitalisierung. Religiosität in Deutschland und Polen im Vergleich (s. 135-146). Wiesbaden: Springer.

Rozporządzenie Ministra Zdrowia (2020a). Rozporządzenie Ministra Zdrowia z dnia 13 marca 2020 r. w sprawie ogłoszenia na obszarze Rzeczypospolitej Polskiej stanu zagrożenia epidemicznego, Dz.U. z 13 marca 2020 r. poz. 433.

Rozporządzenie Ministra Zdrowia (2020b). Rozporządzenie Ministra Zdrowia z dnia 24 marca 2020 r. zmieniające rozporządzenie w sprawie ogłoszenia na obszarze Rzeczypospolitej Polskiej stanu epidemii, Dz.U. z 24 marca 2020 poz. 522.

Rozporządzenie Rady Ministrów (2020). Rozporządzenie Rady Ministrów z dnia 19 kwietnia 2020 r. w sprawie ustanowienia określonych ograniczeń, nakazów i zakazów w związku z wystąpieniem stanu epidemii, Dz.U. z dnia 19 kwietnia 2020 r. poz. 697. 
Sadłoń W. (2014a), Religijny kapitał społeczny. Kapitał społeczny a Kościół katolicki w społecznościach lokalnych $w$ Polsce, Saarbrücken: Wydawnictwo Bezkresy Wiedzy.

Sadłoń W. (2014b). Kościelny trzeci sektor w Polsce oraz działalność charytatywna. W: P. Ciecieląg i in. (red.). Kościół katolicki w Polsce 1991-2011. Rocznik statystyczny (s. 208-219). Warszawa: Główny Urząd Statystyczny.

Sadłoń W. (2016a). Zwischen Volksreligiosität und gemeinnütziger Tätigkeit. Die aktuelle Diskussion um die Finanzierung der Kirche in Polen. W: K. Abmeier (red.). Geld, Gott und Glaubwürdigkeit (s. 155-164). Paderborn: Ferdinand Schöningh Verlag.

Sadłoń W. (2016b). Differentiation, Polarization and Religious Change in Poland. The Religious Studies Review, 262 (4), 25-42.

Sadłoń W. (2016c). Kult Matki Bożej i Nabożeństwo Fatimskie w parafiach katolickich w Polsce. Raport z badania. Salvatoris Mater, 18 (1), 454-479.

Sadłoń W. (2019). Ciągłość i zmiana wiejskich parafii katolickich. W: M. Halamska, M. Stanny, J. Wilkin (red.). Ciagłość i zmiana. Sto lat rozwoju polskiej wsi, tom 1 (s. 351-387). Warszawa: Instytut Rozwoju Wsi i Rolnictwa PAN.

Sadłoń W. (2020). Students' religiosity in their own assessment. W: S. Zaręba, M. Zarzecki (red.). Between Construction and Deconstruction of the Universes of Meaning. Research into the Religiosity of Academic Youth in the Years 1988-1998-2005-2017 (s. 125-146). Berlin: Peter Lang.

Sadłoń W. i in. (2019). Czas wolny w życiu Polaków a świętowanie niedzieli. Analiza wyników badań. Warszawa: Instytut Statystyki Kościoła Katolickiego, http://iskk.pl/images/ stories/Instytut/dokumenty/Niedziela_raport_07.10_14.00.pdf (dostęp: 18.06.2020).

Sadłoń W., Kazanecka M. (2016). Podmioty wyznaniowe prowadzące działalność o charakterze pożytku publicznego. W: Sektor non-profit w 2014 r. (s. 148-161). Warszawa: Główny Urząd Statystyczny.

Sadłoń W., Organek L. (2019). Annuarium Statisticum Ecclesaie in Polonia AD 2019, http:// iskk.pl/images/stories/Instytut/dokumenty/Annuarium_Statisticum_2019.pdf(dostęp: 18.06.2020).

Sobestjański K., Bieńkuńska A. (2017). Wartości i postawy wobec wybranych zachowań w przestrzeni społecznej. W: A. Bieńkuńska, T. Piasecki (red.). Jakość życia $w$ Polsce w 2015 r. Wyniki badania spójności społecznej (s. 91-112). Warszawa: Główny Urząd Statystyczny.

Sroczyńska M. (2013). Rytuały w młodzieżowym świecie. Studium socjologiczne. Kraków: Wydawnictwo Fall.

Szlachetka W. (2012). Fenomen Szkół Nowej Ewangelizacji. Kraków: Nomos.

Świątkiewicz W. (2013). Między rodziną a życiem publicznym - ciągłość i zmiana orientacji na wartości. W: L. Adamczuk, E. Firlit, W. Zdaniewicz (red.). Postawy społeczno-religijne Polaków 1991-2012 (s. 185-206). Warszawa: Instytut Statystyki Kościoła Katolickiego. Taylor Ch. (2007). A Secular Age. Cambridge: The Belknap Press of Harvard University Press. Wskazania (2020). Wskazania Konferencji Episkopatu Polski dla biskupów odnośnie do sprawowania czynności liturgicznych w najbliższych tygodniach z dnia 21 marca $2020 \mathrm{r}$., https://episkopat.pl/prezydium-episkopatu-przypominamy-o-koniecznosci-udzielenia -kolejnej-dyspensy-2/ (dostęp: 1.07.2020). 
Zaręba S. (2006). Instytucjonalne i pozainstytucjonalne formy przekazu treści religijnych. W: W. Zdaniewicz, S. Zaręba (red.). Młodzież Warszawy - pokolenie pontyfikatu Jana Pawła II (s. 245-260). Warszawa: Instytut Statystyki Kościoła Katolickiego.

\title{
Tightening or Breaking an Immanent Frame? Polish Catholicism and the Coronavirus Epidemic
}

\begin{abstract}
In this article I analyse the changing internal dynamics of Catholicism in the pandemic context. In the first part, I present the dynamics of institutional actions triggered by the feeling of being threatened by Covid-19. Then I characterise the dynamism of Polish Catholicism, highlighting (1) its features such as: massiveness, political agency, interpenetration of the parish and the local community in the countryside, the role of small pastoral groups; (2) the directions of change such as: the erosion of community rituals, institutional saturation, breaking the continuity of religious socialisation, the decline in institutional trust, and (3) factors of religious socialisation such as family and media. The analysis of the available empirical data leads me to the conclusion that the epidemic imposed a specific form on Polish Catholicism, which limited the scope of interactions and collective practices and strengthens the process of weakening religious collective practices and ties with the parish, which has been observed for at least two decades. At the same time, the epidemic strengthens the process of differentiation and the Sadoon link between family ties and religiosity, which is central to Polish Catholicism.
\end{abstract}

Keywords: Catholicism, Covid-19, religiosity. 